\title{
MIĘDZY OCHRONĄ KONKURENCJI A REGULACJĄ SEKTOROWA USTROJOWE GRANICE ROZDZIELENIA OBSZARÓW INGERENCJI PAŃSTWA W GOSPODARCE
}

\section{WSTĘP}

Przedmiotem niniejszego artykułu jest strukturalny opis złożonego kompleksu pewnych szczególnych działań prawnych, jakie państwo podejmuje wobec kilku wybranych, charakteryzujących się pewnymi zbieżnymi cechami sektorów gospodarki. Obszarem badawczym objęto funkcjonowanie tzw. sektorów infrastrukturalnych, tj. telekomunikacyjnego, energetycznego, pocztowego oraz transportu kolejowego. Sektory powyższe, funkcjonujące jeszcze do niedawna w warunkach monopolu naturalnego, podlegają postępującym procesom prywatyzacyjnym. Państwo nie rezygnuje jednak całkowicie $\mathrm{z}$ wpływu na funkcjonowanie tychże sektorów. Tworzy w tym zakresie rozmaite instrumenty, których zadaniem staje się „prawne kształtowanie” niektórych sfer aktywności prowadzonej przez podmioty gospodarcze w nich funkcjonujące. Regulacja jako taka odnosi się do wykonywania określonej aktywności przez podmioty gospodarcze w tzw. sektorach infrastruktury technicznej, opartej na zasadniczej roli sieci służącej przesyłaniu i dostarczaniu określonych dóbr ${ }^{1}$. Sektory powyższe w pierwszej kolejności różnią się tym, iż zasadniczą rolę w ich funkcjonowaniu odgrywają tzw. urządzenia kluczowe (ang. essential facilities) ${ }^{2}$. Wskazać można na znaczącą rolę prawa unijnego

* Autor jest adiunktem w Instytucie Nauk Prawno-Administracyjnych na Wydziale Prawa i Administracji Uniwersytetu Warszawskiego.

1 M. Szydło, Regulacja sektorów infrastrukturalnych jako rodzaj funkcji państwa wobec gospodarki, Warszawa 2005, s. 53.

2 Szerzej na temat doktryny essential facilities por. m.in. J. Majcher, Dostęp do urzadzeń kluczowych w świetle orzecznictwa antymonopolowego, Warszawa 2005, szczególnie strony 56 i nast. oraz 83 i nast. 
w kształtowaniu systemu prawa regulacyjnego w Polsce. Jest ona związana przede wszystkim $\mathrm{z}$ obowiązkiem realizacji w prawie krajowym określonych wymogów w bardzo zróżnicowanych obszarach oddziaływania (od konieczności zapewnienia niezależności krajowego organu regulacyjnego do specyficznych obowiązków regulacji prawnej konkretnych sfer aktywności przedsiębiorstw sektorowych).

Państwo powinno posiadać w swoim ręku szereg skutecznych instrumentów, dzięki którym będzie w stanie oddziaływać na podmioty gospodarcze przejawiające aktywność w tych sektorach gospodarki, które związane są z zaspokajaniem potrzeb użyteczności publicznej. Nie przestaje ono jednak w ogóle interesować się zadaniami, z których wykonywania dobrowolnie zrezygnowało. Państwo nie może bowiem zrzucić $\mathrm{z}$ siebie w sposób całkowity odpowiedzialności za dostarczanie usług publicznych obywatelom ${ }^{3}$. Pozostają one $\mathrm{w}$ dalszym ciągu dla niego istotne, jednakże dochodzi do zmiany zespołu środków (instrumentarium) służących wpływowi na wykonywanie tychże usług - wpływ ten staje się jedynie pośredni.

Dokonując procesów liberalizacji w gospodarce, państwo pozostawia sobie wiele władczych środków oddziaływania $\mathrm{z}$ instrumentami regulacyjnymi włącznie. Instrumenty liberalizacji przynależą do sfery interwencjonizmu. Regulacja jako taka jest formą interwencjonizmu państwowego za pomocą instrumentów oddziaływania ex ante, które w swoim założeniu mają doprowadzić do liberalizacji rynku. Podstawową przesłanką regulacji sektorowej jest istnienie niedoskonałości rynku (ang. market failure). Zwłaszcza te podmioty, które funkcjonują w ramach monopolu naturalnego, nie poddają się samoregulacji rynkowej. W związku z powyższym muszą istnieć mechanizmy powodujące wymuszenie na nich określonych zmian służących zwiększeniu konkurencji na rynku ${ }^{4}$.

Założeniem podstawowym staje się stwierdzenie, że pojawienie się funkcji państwa zwanej regulacją sektorową związane jest $\mathrm{z}$ dążeniem do wywołania stanu konkurencji na określonych rynkach. Regulacje sektorowe nie charakteryzują się jednakże brakiem samoistnego charakteru w tym sensie, iż obok dążenia do osiągnięcia celów prokonkurencyjnych, regulacja taka ma również określone cele prospołeczne. Nie zmienia to jednakże faktu, iż podstawowym uzasadnieniem funkcjonowania $\mathrm{w}$ danym porządku prawnym instrumentów należących do tzw. regulacji sektorowej jest dążenie do pojawienia się konkurencji na rynku. W chwili obecnej pojęcie funkcji regulacyjnej państwa w gospodarce jest immanentnie powiązane z dążeniem do wytworzenia stanu konkurencji na określonym rynku. Można wręcz wyrazić pogląd, że regulacja jako taka stanowi subsydiarny element

\footnotetext{
K. Strzyczkowski, Prawo gospodarcze publiczne, Warszawa 2007, s. 149.

4 W. Szpringer, Regulacja konkurencji a konkurencja regulacyjna. Ujęcie instytucjonalne, Warsza-
} wa 2010 , s. 56 . 
kreacji mechanizmów konkurencji w danym sektorze infrastrukturalnym gospodarki. W jednym ze swoich orzeczeń Sąd Najwyższy stwierdzil, że „rynek funkcjonuje prawidłowo tylko wówczas, gdy zapewniona jest możliwość powstania i rozwoju konkurencji, pojmowanej jako zjawisko funkcjonowania gospodarki”5.

Należy wskazać, że w stosunku do sektorów infrastrukturalnych stosuje się jednocześnie regulacje prawa konkurencji (prawa antymonopolowego). W literaturze przedmiotu podejmuje się również problem „normatywnego umiejscowienia" regulacji sektorowej. W. Hoff słusznie wskazuje, że grupa norm prawnych ujmowanych w swoisty system tzw. prawa regulacyjnego tworzy wraz z prawem konkurencji „parę nierozerwalnie związanych ze sobą podsystemów prawa go-

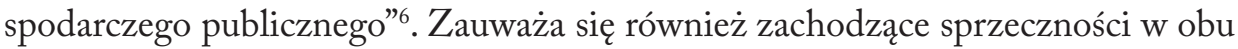
tychże sferach instrumentarium prawnego ${ }^{7}$.

Obowiązujące $\mathrm{w}$ danym porządku prawnym przepisy prawa konkurencji oraz przepisy wchodzące w skład tzw. regulacji sektorowej są instrumentami prawnymi, których rolą jest kształtowanie struktury oraz funkcjonowania tzw. sektorów infrastrukturalnych. Równoległe stosowanie obu tychże reżimów prawnych budzi liczne kontrowersje i wywołuje szereg wątpliwości związanych z możliwością zastosowania norm prawnych pochodzących $\mathrm{z}$ różnych reżimów prawnych do jednego stanu faktycznego. Stosowanie mechanizmów regulacji sektorowej oraz konkurencji znajduje zastosowanie zarówno na szczeblu krajowym, jak i unijnym ${ }^{8}$.

„Normowanie” przez państwo problematyki ochrony konkurencji na rynku obecnie stanowi swoisty standard w katalogu interwencyjnych działań państwa w gospodarce ${ }^{9}$. Zarówno zakres przedmiotowy, jak i podmiotowy prawa konkurencji nie wzbudzają większych kontrowersji. Inaczej natomiast przedstawia się kwestia tworzenia dodatkowych mechanizmów prawnych o charakterze regulacyjnym, które dotyczą tych sfer, gdzie mechanizm rynkowy zawodzi, a prawo konkurencji nie jest w stanie skutecznie przeciwdziałać nadużywaniu siły rynkowej przez funkcjonujących na nim przedsiębiorców.

Regulacja, jako władcze oddziaływanie państwa na podmioty gospodarcze, dokonywana jest przez wyspecjalizowane organy administracji publicznej, cechujące się dużą niezależnością (wymóg wprowadzany dyrektywami unijnymi), mimo że pozostają $\mathrm{w}$ sferze centralnej administracji rządowej. Organy te podejmują roz-

5 Wyrok Sądu Najwyższego z dnia 29 maja 2001 r., I CKN/217/98, niepubl.

W. Hoff, Prawny model regulacji sektorowej, Warszawa 2008, s. 35.

7 C. Banasiński, Równoległe stosowanie prawa konkurencji i instrumentów regulacyjnych w Polsce (na przyktadzie telekomunikacji i energetyki), [w:] C. Banasiński (red.), Prawo konkurencji-stan obecny oraz przerwidywane kierunki zmian, UOKiK, Warszawa 2006, s. 95.

8 Por. szeroko w tym zakresie M. Szydło, Prawo konkurencji a regulacja sektorowa, Warszawa 2010.

9 C. Banasiński, op. cit., s. 96. 
strzygnięcia w sposób zdecydowanie odmienny niż „tradycyjne” organy administracji publicznej. Problematyka wzajemnych relacji pomiędzy przepisami prawa konkurencji oraz prawa regulacji sektorowej wynika więc również z faktu, iż obie grupy instrumentów prawnych są wykonywane przez rozmaite organy. Przepisy wchodzące w zakres prawa regulacji sektorowej wykonują tzw. regulatorzy rynku, posiadający status centralnych organów administracji rządowej ${ }^{10}$, przepisy prawa antymonopolowego zaś inny organ centralny, jakim jest Prezes Urzędu Ochrony Konkurencji i Konsumentów ${ }^{11}$.

Mówiąc o współegzystencji obu odmiennych grup instrumentów prawnych, można wskazać na wzajemne przenikanie się rozwiązań ustrojowych oraz materialnoprawnych. W obszarze ustrojowym zauważalne jest wzajemne oddziaływanie powoływanych przez państwo organów ochrony konkurencji oraz organów regulacji sektorowej w działalność przedsiębiorców funkcjonujących w sektorach infrastrukturalnych. W obszarze materialnoprawnym współwystępowanie obydwu grup instrumentów zakłada w pierwszej kolejności ich wzajemne oddziaływanie oparte na procesie realizacji norm prawnych o charakterze ustawowym oraz podstawowym, służących promowaniu i rozwojowi konkurencji.

Problemem spornym w kontekście wykonywania odpowiedzialności za realizację polityki regulacyjnej oraz polityki konkurencji jest rozstrzygnięcie kwestii ustroju organów administracji posiadających kompetencje w obu tychże obszarach (konkurencji oraz regulacji). Obecnie proces stosowania instrumentów należących do obu sfer nie przebiega bowiem bezkonfliktowo. Kwestie związane $\mathrm{z}$ rozdzieleniem wykonywania polityki konkurencji oraz polityki regulacyjnej $\mathrm{w}$ danym sektorze infrastrukturalnym stały się przedmiotem sporów w doktrynie. Są również punktem zainteresowania orzecznictwa sądowego. Prezentacja powyższych zagadnień oparta zostanie w szczególności na próbie odpowiedzi na pytanie związane $\mathrm{z}$ zasadnością dalszego istnienia w systemie administracji publicznej organów o charterze regulacyjnym oraz organu ochrony konkurencji. Przedmiotem niniejszego artykułu pozostaną więc problemy współegzystencji instrumentów regulacji sektorowej oraz konkurencji. Pozwoli to jednocześnie odpowiedzieć na pytanie, czy stosowanie prawa konkurencji jest dopuszczalne również przez organy wykonujące funkcje organu sektorowego. Prezentacja wzajemnych relacji zachodzących pomiędzy regulacjami sektorowymi a przepisami prawa konkurencji poprzedzona zostanie opisem pojęcia regulacji sektorowej.

10 W Polsce regulatorami rynku są: Prezes Urzędu Regulacji Energetyki, Prezes Urzędu Komunikacji Elektronicznej oraz Prezes Urzędu Transportu Kolejowego.

11 Dalej „Prezes UOKiK”. 


\section{REGULACJA JAKO FUNKCJA ADMINISTRACJI GOSPODARCZEJ}

Jako nowy instrument interwencjonizmu państwowego w gospodarce regulacja pojawiła się w Stanach Zjednoczonych Ameryki Północnej w latach 20. ubiegłego stulecia i objęła swoim oddziaływaniem początkowo sektor energetyczny ${ }^{12}$. Stosunkowo szybko została wprowadzona również na kontynencie europejskim. Regulacja jako element interwencjonizmu gospodarczego pojawiła się nie tylko w systemie prawodawstw krajowych, ale również jako element unijnego porządku prawnego ${ }^{13}$.

Pojęcie regulacji ma swój źródłosłów łaciński - słowo regulatio oznacza „uporządkowywanie”, ,regulowanie"14. Pojęcie regulacji (a ściślej rzecz ujmując - regulacji administracyjnoprawnej) jest więc współcześnie traktowane jako jeden z rodzajów funkcji administracji w sferze gospodarczej ${ }^{15}$. Regulacja staje się przy tym instrumentem o odmiennym charakterze niż typowy, występujący w obszarze oddziaływania przez państwo na gospodarkę klasyczny nadzór administracyjny. W stosunku do tego ostatniego regulacja jest instrumentem oddziaływania ex ante. Nadzór administracyjny odnosi się natomiast do dokonanego już (przeszłego) zachowania przedsiębiorcy. Jego celem staje się ustalenie ex post, czy to zachowanie lub zamiar takiego zachowania jest zgodne $\mathrm{z}$ prawem, tj. czy przedsiębiorca przestrzega nakazów, zakazów, obowiązków itp. ${ }^{16}$ Regulacja w sensie szerokim oznacza (za doktryną niemiecką) wiążące wyznaczenie określonych wzorców zachowań oraz autorytatywne konkretyzowanie tych wzorców w przyszłości ${ }^{17}$. W definicji tej wyraźnie wskazuje się jako dominujące środki oddziaływania te, które mają charakter ex ante. Jak wskazuje C. Banasiński, istotą funkcji regulacyjnej jest ,jej antycypujący sytuację na rynku charakter"18. W przeciwieństwie do klasycznego

12 Por. m.in. J. D. Kearney, T. W. Merrill, The Great Transformation of Regulated Industries Law, „Columbia Law Review” 2006, vol. 98, s. 1329; S. R. Saxer, Government Power Unleashed: Using Emitent Domain to Aquire a Public Utility or Other Ongoing Enterprise, „Indiana Law Rewiev” 2008, vol. 38, s. 62 oraz s. 63; w polskiej literaturze zaś W. Hoff, Polski model regulacji na tle porównawuczym, „Problemy Zarządzania” 2004, nr 3, s. 128.

13 Por. w tym zakresie m.in. M. Szydło, Prawo konkurencji a regulacja sektorowa..., s. 217 i nast.

14 J. Pieńkos, Stownik tacińsko-polski, Warszawa 1993, s. 327-328.

15 Szerzej na temat pojęcia funkcji administracji gospodarczej oraz jej rodzajów - K. Kiczka, Funkcje administracji gospodarczej jako przedmiot badań, [w:] B. Popowska (red.), Funkcje wspótczesnej administracji gospodarczej. Ksiegga dedykowana Profesor Teresie Rabskiej, Poznań 2006, s. 39 i nast.

16 T. Skoczny, Stan i tendencje rozwojowe prawa administracji regulacyjnej w Polsce, [w:] Ius Publicum Europeum. Dwunaste Polsko-Niemieckie Kolokwium Prawników-Administratywistów, Warszawa, 20-22 września 2001 r., Warszawa 2003, s. 117.

17 Por. m.in. poglądy wyrażone w doktrynie niemieckiej - R. Schmidt, Oeffentliches Wirtschaftrecht. Allgemeiner Teil, Berlin 1990, s. 48. Pogląd powyższy w polskiej literaturze przedmiotu przejmuje M. Szydło, Regulacja sektorów infrastrukturalnych..., s. 38.

18 C. Banasiński, op. cit., s. 95. 
nadzoru administracyjnego, instrumenty regulacji sektorowej służą do ingerencji w przyszłe zachowanie podmiotów gospodarczych celem ukształtowania sposobu ich funkcjonowania (wywołanie określonych skutków w rynku).

Pojęcie regulacji, jako swoistej funkcji państwa, pojawiło się dosyć licznie w zachodnioeuropejskiej literaturze przedmiotu w latach 80. zeszłego stulecia. Jego rozumienie łączy się w podjętej wówczas dyskusji z tymi obszarami życia społeczno-gospodarczego, w których państwo rezygnuje $\mathrm{z}$ wykonywania określonych zadań samodzielnie i dopuszcza w szerokim zakresie podmioty prywatne. I tak na przykład, G. F. Schuppert zauważał, że funkcja regulacyjna powinna być postrzegana jako specyficzna funkcja nowoczesnego państwa skierowana na ochronę konsumentów korzystających $z$ usług świadczonych $w$ interesie publicznym ${ }^{19}$. Wskazywano również na te aspekty regulacji, które były powiązane z rzeczywistym dostarczaniem określonych usług publicznych siłami niepublicznych producentów za pomocą specyficznego instrumentarium $\mathrm{z}$ wiążącym udziałem odpowiednich organów państwa ${ }^{20}$. Dosyć istotny pogląd w tym względzie przedstawił M. Ruffert, zwracając uwagę, że w zakresie tworzenia modelu regulacji administracyjnoprawnej istotnego znaczenia nabiera przyjęcie przez państwo odpowiedzialności za pojawiające się z prywatyzacją tychże zadań zagrożenia ${ }^{21}$. $Z$ kolei R. M. Schmidt traktuje pojęcie regulacji w dwóch znaczeniach ${ }^{22}$. W znaczeniu szerokim rozumie ją jako państwowe oddziaływanie na przedsiębiorstwa, które częściowo lub całościowo substytuuje konkurencję. W znaczeniu wąskim natomiast - według tego ostatniego autora - pojęcie regulacji związane jest z ogółem dostępnych instrumentów normowanych przez prawo gospodarcze publiczne, których zadaniem jest oddziaływanie na podmioty wykazujące swoją aktywność w sektorze energetycznym.

Na pojęcie regulacji zwracali uwagę również inni autorzy, zwłaszcza w obszarze niemieckojęzycznym, wskazując na pewne autonomiczne cechy tej sfery prawa publicznego $^{23}$. W polskiej literaturze przedmiotu problematyka prawna regulacji - jako przedmiot odrębnych badań lub też badań powiązanych z zagadnieniami

19 G. F. Schuppert, Vom produzierenden zu gewähreleistenden Staat: Privatisierung als Veränderung staatlicher Handlungsformen, [w:] K. König, A. Benz (Hrsg.), Privatisierung und staatliche Regulierung, Baden-Baden 1997, s. 149 i nast.

20 H. Seidman, R. Gilmour, Politics, Position and Power. From the Positive to the Regulatory State, Oxford 1986, s. 120.

21 M. Ruffert, Regulierung im System des Verwaltungsrecht. Grundstrukturen der Privatisirungsfolgerecht der Post und Telekomunikation, „Archiv des Oeffentlichen Recht” 1999, Bd. 124, s. 241.

22 R. Schmidt, op. cit., s. 74 i nast.

23 Wskazać można chociażby na następujące opracowania: L. Gramlich, Entwicklungen der Staatlichen Wirtschafstausicht: Das Telekomunikationsrecht als Models?, „Verwaltungs Archiv” 1997, Nr. 4, s. 624 i nast.; H. H. Trute, Die Verwaltung und das Verwaltungsrecht zwischen gesselschaftlicher Selbstregulierung und staatlicher Steureung, „Deutsches Verwaltungsblatt” 1996, Nr. 17, poz. 950 i nast.; J. Masing, Stan i tendencje rozwojowe regulujacego prawa administracyjnego, [w:] Ius Publi- 
konkurencji - pojawiła się w pierwszej połowie obecnej dekady. Wskazać można przede wszystkim na poglądy wyrażone w tym względzie przez T. Skocznego ${ }^{24}$, natomiast w nowszej literaturze przedmiotu przez M. Szydłę oraz R. Stasikowskiego $^{26}$, W. Hoffa ${ }^{27}$, K. Strzyczkowskiego ${ }^{28}$, E. Kosińskiego ${ }^{29}$ czy w końcu również autora niniejszego artykułu ${ }^{30}$.

Regulacja gospodarcza związana jest więc $z$ oddziaływaniem, za pomocą rozmaitych instrumentów prawnych, na podstawowe obszary organizacji i funkcjonowania przedsiębiorców związane $\mathrm{z}$ prowadzeniem przez nich profesjonalnej działalności, tj. w zakresie dostępu do rynku, w odniesieniu do wielkości produkcji i cen produktów, a także jakości produktów czy dystrybucji.

Podstawowym rodzajem regulacji infrastrukturalnej jest tzw. regulacja prokonkurencyjna ${ }^{31}$. Ma ona w swoim założeniu dążyć do osiągnięcia stanu konkurencji na danym rynku w sektorze infrastrukturalnym. Pojęcie regulacji prokonkurencyjnej będzie więc obejmować wyłącznie te instrumenty oddziaływania w danym sektorze, których zadaniem jest „rozwój”, „promocja”, „wspieranie” konkurencji, wszędzie tam, gdzie mechanizmy konkurencji nie zostały jeszcze wytworzone ${ }^{32}$. Wszędzie zaś tam, gdzie konkurencja już istnieje, mamy do czynienia ze stosowaniem ingerencji regulacyjnej celem jej utrzymania. Podstawowym zadaniem tzw. regulacji prokonkurencyjnej ${ }^{33}$ jest „wywołanie” konkurencji w danym sektorze

cum Europeum. Dwunaste Polsko-Niemieckie Kolokwium Prawników-Administratywistów, Warszawa, 20-22 września 2001 r., Warszawa 2003, s. 165 i nast.

24 Por. m.in. T. Skoczny, Ochrona konkurencji i prokonkurencyjna regulacja sektorowa, „Problemy Zarządzania" 2004, nr 3; idem, Stan i tendencje rozwojowe...; idem, Wspólnotowe prawo regulacji in statu nascendi, [w:] C. Mik (red.), Prawo gospodarcze Wspólnoty Europejskiej na progu XXI wieku, Toruń 2002.

25 M. Szydło, Regulacja sektorów infrastrukturalnych...; idem, Regulacja sektorów infrastrukturalnych jako nowy rodzaj funkcji państwa wobec gospodarki, „Studia Prawnicze” 2004, nr 3; idem, Regulacja sektorowa a ogólne prawo antymonopolowe, „Problemy Zarządzania” 2008, nr 1.

26 R. Stasikowski, O istocie regulacji administracyjnoprawnej, „Przegląd Prawa Publicznego” 2008, nr 11.

27 W. Hoff, Prawny model regulacji...; idem, Polski model regulacji...

28 K. Strzyczkowski, op. cit., s. 165-166.

29 E. Kosiński, Regulacja prokonkurencyjna nowa funkcja państwa? Rozważania na przyktadzie regulacji sektora elektroenergetycznego Unii Europejskiej, [w:] B. Popowska (red.), Funkcje wspótczesnej administracji gospodarczej. Księga dedykowana Profesor Teresie Rabskiej, Poznań 2006.

30 R. Stankiewicz, Kilka uwag o regulacji jako funkcji administracji gospodarczej w rozwoju sektora energetycznego, [w:] M. Wierzbowski, R. Stankiewicz (red.), Wspótczesne problemy prawa energetycznego, Warszawa 2010, s. 104 i nast.

31 T. Skoczny, Ochrona konkurencji i prokonkurencyjna..., s. 14.

32 Pojęcie regulacji prokonkurencyjnej zawarte m.in. w: T. Skoczny, Ochrona konkurencji i prokonkurencyjna..., s. 14; C. Banasiński, op. cit., s. 95.

33 Zwanej także regulacją dla rynku (ang. regulation for the market), konkurencją przez regulację (ang. competition through regulation), regulacją na rzecz konkurencji (ang. regulation from competition) - por. w tym zakresie - R. Stankiewicz, Kilka uwag o regulacji..., s. 141. 
gospodarki czy przynajmniej stworzenie tzw. efektu rynku (inaczej „efektu konkurencji”) na rynkach wcześniej niekonkurencyjnych, na których funkcjonowały państwowe monopole prawne ${ }^{34}$. Regulacja prokonkurencyjna ma zagwarantować niwelowanie wszelkich barier dostępu do rynku, zmuszenie naturalnych monopolistów do racjonalnego i efektywnego gospodarowania, kreuje nadzór nad taryfami i cenami, ochronę praw odbiorców i konsumentów, wprowadzanie innowacji technologicznych oraz utrzymanie określonego, minimalnego poziomu jakości towarów i usług ${ }^{35}$.

\section{PODZIAŁ KOMPETENCJI POMIĘDZY REGULATOREM RYNKU A ORGANEM OCHRONY KONKURENCJI}

Jak wskazano powyżej, istotą funkcji regulacji sektorowej jest jej antycypujący wymiar oddziaływania na rynek. Celem stosowania instrumentów prawnych z zakresu regulacji sektorowej powinno być powstanie rynku konkurencyjnego w danej dziedzinie. Cecha ta nie przesądza jednak ostatecznie o zakresie zadań danego regulatora rynku, a jednocześnie nie przesądza o podziale kompetencji pomiędzy organami regulacyjnymi oraz organem antymonopolowym.

W doktrynie formułuje się różnorodne sposoby wpływu prawa regulacyjnego oraz prawa ochrony konkurencji na kształtowanie sektorów. Podstawowa różnica wynika $\mathrm{z}$ odmiennego zakresu wykorzystania instrumentów regulacyjnych oraz instrumentów ochrony konkurencji. Ma to w pewnym zakresie wpływ na sposób podziału kompetencji pomiędzy organy regulacyjne i organy ochrony konkurencji. Modelem najbardziej radykalnym jest przeprowadzenie pełnej liberalizacji sektora oraz prywatyzacji zrestrukturyzowanego monopolisty sieciowego, przy jednoczesnym wyodrębnieniu infrastruktury sieciowej, czego efektem powinno być powierzenie kompetencji w zakresie ochrony konkurencji wyłącznie organowi antymonopolowemu. $Z$ kolei model przeciwny przewiduje przyjęcie podejścia ewolucyjnego, zakładającego stopniowy proces reformy danego sektora. W modelu tym dochodzi do pojawiającego się etapami wchodzenia na dany rynek sektora infrastrukturalnego gospodarki konkurentów dotychczasowego monopolisty. To podejście jest związane $z$ koniecznością powołania organu regulacyjnego oraz szerszym stosowaniem metody regulacji sektorowej ${ }^{36}$. Zakłada to jednocześnie ograniczoną rolę organu ochrony konkurencji w takim systemie. Model powyższy polega jednocześnie na podziale zadań pomiędzy organy regulacji sektorowej

\footnotetext{
K. Strzyczkowski, op. cit., s. 176-177.

H. Palarz, Prawo energetyczne z komentarzem, Gdańsk 2004, s. 40.

C. Banasiński, op. cit., s. 97.
} 
oraz organy ochrony konkurencji. Jest to model dominujący w państwach członkowskich Unii Europejskiej ${ }^{37}$. W założeniu wskazana reforma strukturalna ma ułatwić realizację polityki zmierzającej do stopniowej likwidacji tradycyjnych monopoli istniejących w tych sektorach. Obok tego regulatora rynku istnieje oczywiście w Niemczech organ ochrony konkurencji ${ }^{38}$. Zgodnie natomiast $\mathrm{z}$ niemiecką ustawą o przeciwdziałaniu ograniczeniom konkurencji, jeżeli przepisy ww. ustawy nie przyznają uprawnień innym organom, sprawy rozstrzyga organ ochrony konkurencji. Rozwiązanie takie zakłada więc przekazanie kompetencji w zakresie ochrony konkurencji również organom będącym regulatorami rynku. Organ regulacyjny posiada więc kompetencję do wydawania decyzji administracyjnych, stwierdzających praktyki naruszające konkurencję, a także nakładania kar pieniężnych na przedsiębiorców funkcjonujących w danym sektorze infrastrukturalnym.

Interesujące rozwiązanie strukturalne zostało wypracowane w Wielkiej Brytanii. Rozwiązanie to nazywane jest modelem współdecydowania lub też modelem równoczesnych uprawnień. Oznacza to, że organowi regulacyjnemu przyznano również, oprócz instrumentów regulacyjnych wobec określonego sektora, kompetencje odpowiadające uprawnieniom organu antymonopolowego, odnoszące się do całej gospodarki. Organ regulacyjny ma możliwość wydawania decyzji administracyjnych, stwierdzających praktyki naruszające konkurencję, a także nakładania kar pieniężnych w określonym sektorze $\mathrm{e}^{39}$.

W Polsce brak jest jednoznacznych regulacji prawnych dokonujących rozdziału kompetencji pomiędzy organem ochrony konkurencji (Prezesem UOKiK) a organami regulacyjnymi. W związku z powyższym autonomia regulacji sektorowej (rozumianej jako zbiór przepisów ustanawiających określone nakazy lub zakazy zachowań wobec podmiotów funkcjonujących w ramach danego sektora) wobec przepisów regulacji ochrony konkurencji powinna istnieć w tych obszarach, gdzie przepisy danej regulacji sektorowej skonstruowano w taki sposób, że ich brzmienie wydaje się również wypełniać treść przepisów służących ochronie i rozwojowi konkurencji ${ }^{40}$.

37 Przy czym najczęściej powołuje się poszczególne organy regulacyjne do określonych sektorów gospodarki, rzadziej łączy się je w jeden organ regulacyjny. To ostatnie rozwiązanie przyjęto kilka lat temu w Niemczech, gdzie na podstawie ustawy z dnia 7 lipca 2005 r. - Gesetz uber die Bundesnetzagentur fur Elektrizitaet, Gas, Telekommunikation, Post und Eisenbahn, nastąpiło połączenie regulatorów branżowych i powstanie jednego regulatora (niem. Bundesnetzagentur), który swoim działaniem obejmuje telekomunikację, pocztę, energetykę oraz transport kolejowy.

38 Federalny Urząd Antymonopolowy (niem. Bundeskartellamt).

39 Por. w tym zakresie C. Banasiński, op. cit., s. 99 i nast.

40 Por. szerzej na temat podziału tychże kompetencji w obszarze regulacji energetyki R. Stankiewicz, Wzajemne relacje pomiędzy kompetencjami Prezesa UOKiK oraz Prezesa URE w sprawach z zakresu energetyki, [w:] F. M. Elżanowski, M. M. Sokołowski, Systemowe uwarunkowania sektorów strategicznych. Wnioski dla energetyki, Torun 2011, s. 248 i nast. 
Podstawowe problemy, jakie pojawiają się w orzecznictwie sądowym w Polsce $\mathrm{w}$ tym zakresie, wynikają ze stosowania regulacji prawa energetycznego. Interesujące kwestie pojawiły się szczególnie w zakresie rozstrzygania w sprawach związanych z praktykami cenowymi stosowanymi przez przedsiębiorstwa energetyczne. Należy wskazać, że Prezes Urzędu Regulacji Energetyki jest uprawniony do badania przedkładanych mu przez określone przedsiębiorstwa energetyczne taryf cenowych pod względem ich zgodności z odpowiednimi rozwiązaniami zawartymi w ustawie - Prawo energetyczne ${ }^{41}$, uprawnieniem tego organu jest zatwierdzanie tychże taryf ${ }^{42}$. Z kolei Prezes UOKiK jest uprawniony do sprawowania nadzoru nad praktykami cenowymi stosowanymi przez poszczególnych przedsiębiorców na rynku. Organ ochrony konkurencji dokonuje takiej oceny na podstawie przesłanek zawartych w art. 9 Ustawy z dnia 16 lutego 2007 r. o ochronie konkurencji i konsumentów ${ }^{43}$. W tym zakresie pojawia się pytanie, czy stosowanie przez przedsiębiorstwo energetyczne cen w oparciu o zatwierdzoną przez Prezesa Urzędu Regulacji Energetyki taryfę może być kwestionowane przez Prezesa UOKiK jako działanie sprzeczne $z$ prawem antymonopolowym. Zgodnie z poglądem wyrażonym w orzecznictwie, przepisy ustawy antymonopolowej nie mogą stanowić podstawy do kwestionowania wysokości zatwierdzonych taryf na podstawie art. 47 ustawy - Prawo energetyczne. W judykaturze podkreśla się, że stosowanie przez przedsiębiorstwo energetyczne cen zgodnie $z$ zatwierdzoną przez Prezesa Urzędu Regulacji Energetyki taryfą cenową powoduje, że niemożliwe jest wówczas uznanie, iż przedsiębiorca taki stosuje praktyki ograniczające konkurencję polegające na bezpośrednim lub pośrednim narzucaniu nieuczciwych cen, w tym nadmiernie wygórowanych lub rażąco niskich ${ }^{44}$.

Sąd Najwyższy w swoim orzecznictwie potwierdził wyraźnie, że ceny i stawki opłat określone w taryfie ustalonej przez przedsiębiorców sektora energetycznego i obowiązujące w wyniku ich zatwierdzenia przez organ sektorowy, a następnie prawidłowo ogłoszone, nie mogą być przedmiotem kontroli w postępowaniu antymonopolowym prowadzonym przez Prezesa UOKiK na podstawie przepisów ustawy antymonopolowej ${ }^{45}$. Sąd Ochrony Konkurencji i Konsumentów stwierdził jednocześnie, że Prezes UOKiK może wszcząć postępowanie antymonopolowe przeciwko przedsiębiorstwu energetycznemu stosującemu określone praktyki cenowe, jeżeli regulacja w danym zakresie nie została jeszcze przez Prezesa Urzędu

41 Ustawa z dnia 10 kwietnia 1997 r. - Prawo energetyczne (tekst jedn. z 2006 r. Dz. U. nr 89, poz. $625 \mathrm{ze} \mathrm{zm}$.).

42 Por. art. 44-47 ustawy - Prawo energetyczne.

43 Ustawa z dnia 16 lutego 2007 r. o ochronie konkurencji i konsumentów (Dz. U. nr 50, poz. 331 ze zm.).

44 Por. wyrok Sądu Najwyższego z dnia 7 kwietnia 2004 r., IV CK 215/03, niepubl.

45 Wyrok Sądu Najwyższego z dnia 25 maja 2004 r., III SK 48/04, OSNP 2005, nr 10, poz. 51. 
Regulacji Energetyki dokonana ${ }^{46}$. W opinii sądu byłoby to możliwe, jeśli organ sektorowy nie zatwierdził jeszcze taryfy danego przedsiębiorstwa (ewentualnie w ogóle nie jest uprawniony do zatwierdzania jego taryf $)^{47}$.

W polskiej literaturze przedmiotu wskazuje się również, że niezależność i autonomiczność regulacji sektorowej wobec działalności Prezesa UOKiK powinna iść nawet jeszcze dalej, niż to przyjmuje judykatura. Wszędzie tam bowiem, gdzie przepisy regulacji sektorowej są wystarczająco szczegółowe, można by je uznać za lex specialis $\mathrm{w}$ stosunku do przepisów ustawy antymonopolowej, a gdzie regulator sektorowy posiada stosowne kompetencje do podejmowania określonych rozstrzygnięć (np. w zakresie zatwierdzania cen), tam równocześnie wyłączone są kompetencje orzecznicze Prezesa UOKiK, nawet jeżeli regulator sektorowy nie podjął jeszcze określonego rozstrzygnięcia ${ }^{48}$. W przekonaniu autora niniejszego opracowania podjęcie rozstrzygnięcia reglamentacyjnego w określonym zakresie przez organ regulacji sektorowej wyklucza możliwość „następczej aktywności” Prezesa UOKiK, którego rozstrzygnięcie mogłoby podważyć wcześniejsze rozstrzygnięcie regulatora rynku.

\section{ZAKOŃCZENIE}

Instytucja regulacji infrastrukturalnej odgrywa zasadniczą rolę w kształtowaniu podstaw rozwoju sektorów gospodarki nią objętych. Normatywna regulacja rynku w danym sektorze w Polsce wykazuje wszystkie istotne cechy regulacji prokonkurencyjnej. Instrumenty zaliczane do omawianej sfery służą osiąganiu dobra wspólnego. Podkreślić należy, że celem regulacji prokonkurencyjnej jest ochrona interesów konsumentów, osiągana m.in. przez zapewnienie równego dostępu do rynku dla przedsiębiorców danego sektora infrastrukturalnego. Podstawowym zadaniem tejże sfery regulacji jest stymulowanie rozwoju konkurencji.

Regulacja sektorowa powinna jasno opierać się na celach polityki w danym sektorze (tworzyć instrumenty prawne jej skutecznej realizacji). Rzeczywisty kształt instrumentów regulacyjnych będzie uzależniony w dużej mierze od stanu konkurencji na danym rynku występującym w obrębie sektora infrastrukturalnego. Skoro jednak cele regulacji sektorowej mają przede wszystkim prokonkurencyjny charakter, to organ je wypełniający realizuje instrumenty prawne wynika-

46 Por. wyrok Sądu Ochrony Konkurencji i Konsumentów z dnia 7 stycznia 2004 r., III SK 48/04, OSNP 2005, nr 10, poz. 51.

47 Ibidem.

48 J. Baehr, A. Stawicki, Rozważania wokót równolegtego stosowania prawa konkurencji i instrumentów regulacyjnych, [w:] C. Banasiński (red.), Ochrona konkurencji i konsumentów w Polsce i Unii Europejskiej (studia prawno-ekonomiczne), Warszawa 2005, s. 157. 
jące z ustaw, które służą rozwojowi konkurencji na danym rynku. Trudno więc jednoznacznie stwierdzić, aby organ sektorowy mógł zasadniczo realizować inne zadania niż te określone w zakresie kompetencji Prezesa UOKiK (w przypadku tego ostatniego organu, co wskazano powyżej, jego funkcjonowanie dotyczy wszystkich sektorów gospodarki).

Niewątpliwie konkurencja ,jako polityczny wymiar gospodarki rynkowej”"49 powinna być wspierana i chroniona prawem regulacji sektorowej. Nie ma wątpliwości, że większość instrumentów należących do systemu szeroko rozumianej regulacji sektorowej wykazuje ukierunkowanie na rozwijanie konkurencji. Wywołanie stanu konkurencji na określonym rynku przez przedsiębiorców sektora energetycznego ma gwarantować utrzymanie dostępności usług, ich odpowiedniej jakości, jak również możliwie niskiej ceny. Trwałą cechą regulacji w tym zakresie jest władcza interwencja ex ante organu regulacyjnego na danym rynku. Budowanie skutecznej konkurencji, w przeciwieństwie do korygowania jej zniekształceń, jak w prawie ochrony konkurencji, jest najbardziej charakterystycznym celem działań regulacyjnych.

Antycypujący charakter mechanizmów regulacyjnych ukierunkowanych w przeważającej mierze na kreację konkurencyjnych mechanizmów funkcjonowania sektora energetycznego nie wyklucza, że w jego obszarze znajdą zastosowanie przepisy prawa antymonopolowego - Ustawy z dnia 16 lutego 2007 r. o ochronie konkurencji i konsumentów. Zawarte w przepisach prawa konkurencji oraz prawa regulacji sektorowej instrumenty prawne mogą ingerować w te same obszary funkcjonowania przedsiębiorców. Podstawowym celem działania staje się rozwój oraz ochrona efektywnej konkurencji. Wskazać jednak należy, że wszędzie tam, gdzie organ regulacyjny rozstrzygnął już o istocie uprawnień lub obowiązków podmiotu nadzorowanego, nie powinno dochodzić do następczej ingerencji organu antymonopolowego. $Z$ punktu widzenia efektywnościowego działania prawa istotne jest, aby wykonywanie kompetencji wskazanych organów nie dublowało się w stosunku do jednego i tego samego zdarzenia jednocześnie. Przyjęcie odmiennego założenia byłoby działaniem nieracjonalnym i powodowałoby utratę zaufania do organów państwa.

Rynki regulowane, jak rynek telekomunikacyjny, pocztowy, energetyczny czy rynek transportu kolejowego, nadal nie są rynkami całkowicie zliberalizowanymi. Regulacja sektorowa ma służyć rozwojowi konkurencji na tychże rynkach. Proces ten wydaje się jeszcze długi. Trudno jednoznacznie określić, jaki stan konkurencji na rynkach infrastrukturalnych może być uznany za „moment finalny”. Ustawodawca kreuje określone środki regulacji sektorowej w oparciu o założony cel poziomu liberalizacji danej części rynku.

49 T. Skoczny, Stan i tendencje rozwojowe..., s. 116. 
W związku z tym, iż proces liberalizacji sektorów infrastrukturalnych w Polsce nie osiągnął jeszcze wystarczającego poziomu, niezbędne jest utrzymanie odrębnych organów regulacyjnych w takiej formie, jak ma to miejsce obecnie. Połączenie organów regulacyjnych $\mathrm{z}$ organem ochrony konkurencji (a właściwie włączenie ich kompetencji do Urzędu Ochrony Konkurencji i Konsumentów) mogłoby osłabić skuteczność działania zarówno regulatorów, jak i samego organu ochrony konkurencji.

Jak wskazano to wielokrotnie powyżej, inny jest charakter działań podejmowanych przez organy regulacyjne (oddziaływanie ex ante), inny zaś organu ochrony konkurencji. Odrębność specyfiki zadań organu ochrony konkurencji oraz zadań regulatora rynku nie powoduje jednak zachodzących zbieżności kompetencyjnych. Jak wskazano powyżej, kwestie sporne rozwiązuje jednakże orzecznictwo sądowe.

Jak się wydaje, brak jest również powodów, aby wskazywać, że połączenie funkcji regulacyjnych $z$ funkcjami ochrony konkurencji w kompetencji jednego organu centralnego byłoby zasadne. Zgodzić należy się z poglądem wyrażonym w literaturze przedmiotu, iż pomiędzy tymi organami powinna jednak istnieć współpraca oraz współdziałanie ${ }^{50}$. Zasadne jest normatywne ukształtowanie tego typu zachowań również przy użyciu rozwiązań przewidzianych w przepisach proceduralnych, którymi związany jest organ administracji wydający decyzje administracyjne ${ }^{51}$. De lege ferenda, należałoby wprowadzać do regulacji sektorowych rozwiązania zakładające współdziałanie organu ochrony konkurencji przy wydawaniu decyzji należących do regulatorów rynku. Istnieje więc możliwość współdziałania tychże organów przy wydawaniu rozstrzygnięć. Nie jest natomiast zasadny pogląd wskazujący na konieczność przekazania części istniejących kompetencji regulacyjnych Prezesowi $\mathrm{UOKiK}^{52}$.

Jak się wydaje, trwały wzrost konkurencyjności rynków powiązanych z działalnością przedsiębiorców danego sektora infrastrukturalnego nie wyeliminuje regulacji jako instrumentu oddziaływania na rozwój takiego sektora. Mechanizmy regulacyjne kreują większą skuteczność założonych celów, gdyż działają w spo-

50 M. Szydło, Prawo konkurencji..., s. 313.

51 Organy mogłyby współdziałać wykorzystując art. 106 Ustawy z dnia 14 czerwca $1960 \mathrm{r}$. Kodeks postępowania administracyjnego (tekst jedn. z 2000 r. Dz. U. nr 30, poz. 1071 ze zm.). Należy jednak wskazać, iż wykorzystanie instytucji współdziałania możliwe jest tylko wówczas, gdy ustawodawca przewiduje taką możliwość w regulacjach szczególnych. Należałoby wnioskować wprowadzenie takich postanowień do Ustawy - Prawo energetyczne (i innych regulacji sektorowych) we wszystkich tych regulacjach normatywnych, gdzie ustawodawca przewiduje kompetencje do wydawania decyzji organowi regulacyjnego wobec przedsiębiorców w zakresie promowania konkurencji. Wydając taką decyzję, organ regulacyjny miałby obowiązek wystąpić o zajęcie stanowiska w danej sprawie do Prezesa UOKiK.

52 M. Szydło, Prawo konkurencji..., s. 313. 
sób uprzedzający, planowy. Dzięki mechanizmom o regulacyjnym charakterze państwo oddziaływuje na przyszłe zachowanie przedsiębiorcy, czyniąc jego aktywność w danym sektorze gospodarczym bardziej pożądaną z punktu widzenia korzyści ogólnospołecznych. Nie można więc twierdzić, że regulacja to funkcja tymczasowa, której racjonalne podstawy stosowania znikną, kiedy wykształci się i ustabilizuje stan konkurencji na danym rynku obrotu określonym towarem lub usługą. Jak się wydaje, regulacja, jako specyficzny typ oddziaływania na gospodarkę, nie straci swoich racjonalnych podstaw.

Im więcej zróżnicowanych instrumentów prawnych wykonywanych przez rozmaite organy administracji ingeruje w poszczególne sektory infrastrukturalne, tym większe zagrożenie dezintegracją polityki gospodarczej. Zwiększanie się konkurencyjności danego rynku powoduje możliwość ograniczania regulacji sektorowych. W chwili obecnej konieczne jest współwystępowanie obu regulacji jednocześnie. Możliwe jest jednakże współegzystowanie obu grup instrumentów prawnych.

\section{BIBLIOGRAFIA}

Baehr J., Stawicki A., Rozważania wokót równolegtego stosowania prawa konkurencji i instrumentórw regulacyjnych, [w:] C. Banasiński (red.), Ochrona konkurencji i konsumentów w Polsce i Unii Europejskiej (studia prawno-ekonomiczne), Warszawa 2005.

Banasiński C., Równolegte stosowanie prawa konkurencji $i$ instrumentów regulacyjnych w Polsce (na przyktadzie telekomunikacji i energetyki), [w:] C. Banasiński (red.), Prawo konkurencji - stan obecny oraz przewwidy wane kierunki zmian, UOKiK, Warszawa 2006.

Gramlich L., Entwicklungen der Staatlichen Wirtschafstausicht: Das Telekomunikationsrecht als Models?, „Verwaltungs Archiv” 1997, Nr. 4.

Hoff W., Polski model regulacji na tle porównawczym, „Problemy Zarządzania” 2004, nr 3. Hoff W., Prawny model regulacji sektorowej, Warszawa 2008.

Kearney J. D., Merrill T. W., The Great Transformation of Regulated Industries Law, „Columbia Law Review" 2006, vol. 98.

Kiczka K., Funkcje administracji gospodarczej jako przedmiot badań, [w:] B. Popowska (red.), Funkcje wspótczesnej administracji gospodarczej. Księga dedykowana Profesor Teresie Rabskiej, Poznań 2006.

Kosiński E., Regulacja prokonkurencyjna nowa funkcja państwa? Rozważania na przykładzie regulacji sektora elektroenergetycznego Unii Europejskiej, [w:] B. Popowska (red.), Funkcje wspótczesnej administracji gospodarczej. Ksiega dedykowana Profesor Teresie Rabskiej, Poznań 2006.

Majcher J., Dostęp do urzadzeń kluczowych w świetle orzecznictwa antymonopolowego, Warszawa 2005.

Masing J., Stan i tendencje rozwojowe regulującego prawa administracyjnego, [w:] Ius Publicum Europeum. Dwunaste Polsko-Niemieckie Kolokwium Prawników-Administratywistórw, Warszawa, 20-22 września 2001 r., Warszawa 2003. 
Palarz H., Prawo energetyczne z komentarzem, Gdańsk 2004.

Ruffert M., Regulierung im System des Verwaltungsrecht. Grundstrukturen der Privatisirungsfolgerecht der Post und Telekomunikation, „Archiv des Oeffentlichen Recht”1999, Bd. 124.

Saxer S. R., Government Power Unleashed: Using Emitent Domain to Aquire a Public Utility or Other Ongoing Enterprise, „Indiana Law Rewiev” 2008, vol. 38.

Schmidt R., Oeffentliches Wirtschaftrecht. Allgemeiner Teil, Berlin 1990.

Seidman W., Gilmour R., Politics, Position and Power. From the Positive to the Regulatory State, Oxford 1986.

Skoczny T., Wspólnotowe prawo regulacji in statu nascendi, [w:] C. Mik (red.), Prawo gospodarcze Wspólnoty Europejskiej na progu XXI wieku, Torun 2002.

Skoczny T., Stan i tendencje rozwojowe prawa administracji regulacyjnej w Polsce, [w:] Ius Publicum Europeum. Dwunaste Polsko-Niemieckie Kolokwium Prawników-Administratywistów, Warszawa, 20-22 wrzesnia 2001 r., Warszawa 2003.

Skoczny T., Ocbrona konkurencji a prokonkurencyjna regulacja sektorowa, [w:] Ochrona konkurencji i niezależna regulacja sektorowa, „Problemy Zarządzania” 2004, nr 3.

Stankiewicz R., Kilka uwag o regulacji jako funkcji administracji gospodarczej w rozwoju sektora energetycznego, [w:] M. Wierzbowski, R. Stankiewicz (red.), Wspótczesne problemy prawa energetycznego, Warszawa 2010.

Stankiewicz R., Wzajemne relacje pomiędzy kompetencjami Prezesa UOKiK oraz Prezesa URE w sprawach z zakresu energetyki, [w:] F. M. Elżanowski, M. M. Sokołowski, Systemowe uwarunkowania sektorów strategicznych. Wnioski dla energetyki, Torun 2012.

Stasikowski R., O istocie regulacji administracyjnoprawnej, „Przegląd Prawa Publicznego” 2008, nr 11.

Strzyczkowski K., Prawo gospodarcze publiczne, Warszawa 2007.

Szydło M., Regulacja sektorów infrastrukturalnych jako nowy rodzaj funkcji państwa wobec gospodarki, „Studia Prawnicze” 2004, nr 3.

Szydło M., Regulacja sektorów infrastrukturalnych jako rodzaj funkcji państwa wobec gospodarki, Warszawa 2005.

Szydło M., Regulacja sektorowa a ogólne prawo antymonopolowe, „Problemy Zarządzania” 2008, nr 1.

Szydło M., Prawo konkurencji a regulacja sektorowa, Warszawa 2010.

Szpringer W., Regulacja konkurencji a konkurencja regulacyjna. Ujęcie instytucjonalne, Warszawa 2010.

Trute H., Die Verwaltung und das Verwaltungsrecht zwischen gesselschaftlicher Selbstregulierung und staatlicher Steureung, „Deutsches Verwaltungsblatt” 1996, Nr. 17. 


\title{
STRESZCZENIE
}

Regulacje sektorowe obejmują kreację równych dla wszystkich warunków konkurowania na rynku. Regulacje sektorowe są zbieżne z założeniami i treścią prawa antymonopolowego. Natomiast korzyści z regulacji sektorowych w świetle regulacji prawa antymonopolowego są autonomiczne. Decyzje regulatorów sektorowych zastępują decyzje Urzędu Ochrony Konkurencji i Konsumentów.

\section{BETWEEN PROTECTION OF COMPETITION AND SECTOR REGULATION. POLITICAL BORDERS OF SEPARATING AREAS OF STATE INTERFERENCE IN THE MARKET}

\author{
SUMMARY
}

Creating equal conditions of competition on the market is setting the sector regulation. Sector regulations has coincident cells and assumptions, similarly to the antitrust law. Provisions of the sector regulations are autonomous in view of regulations of the antitrust law. The decision of the sector regulator bodies is replacing the decision of the Chairman of the Office of Competition and Consumer Protection. 